\title{
The influence of memorable tourism experience to revisit intention of domestic tourists: A case study for Danang City, Vietnam
}

\author{
Pham Thi Lan Huong ${ }^{1}$, Truong Thi Van Anh ${ }^{1}$, Truong Dinh Quoc Bao ${ }^{1 *}$ \\ ${ }^{1}$ University of Economics, The University of Danang, Danang, Vietnam \\ *Corresponding author: baotdq@due.edu.vn
}

\begin{tabular}{|c|c|}
\hline ARTICLE INFO & ABSTRACT \\
\hline $\begin{array}{l}\text { DOI:10.46223/HCMCOUJS. } \\
\text { econ.en.12.1.1941.2022 }\end{array}$ & $\begin{array}{l}\text { The present study examines the effects of dimensions of } \\
\text { Memorable Tourism Experience (MTE) scale on domestic tourists } \\
\text { revisit intention to Danang tourist destination. An online survey of } \\
309 \text { tourists who has visited Danang for data analysis. The structural }\end{array}$ \\
\hline Received: June $16^{\text {th }}, 2021$ & equation model is applied to investigate the relationships between \\
\hline Revised: July $20^{\text {th }}, 2021$ & MTE's dimensions and tourist's revisit intention. The results show \\
\hline Accepted: July $31^{\text {st }}, 2021$ & $\begin{array}{l}\text { that four dimensions of MTE (Novelty, Involvement, Hedonism, } \\
\text { and Local Culture) have significant positive relationships with } \\
\text { domestic tourists' revisit intention. In contrast, Knowledge is found } \\
\text { to affect tourists' revisit intention negatively. Overall, the study } \\
\text { contributes to the literature on memorable tourism experiences by } \\
\text { offering theoretical and empirical evidence about interrelationships } \\
\text { between the dimensions of memorable tourism experiences and }\end{array}$ \\
\hline $\begin{array}{l}\text { Keywords: } \\
\text { destination experience; } \\
\text { domestic tourists; memorable } \\
\text { tourism experience; revisit } \\
\text { intention; Vietnam }\end{array}$ & $\begin{array}{l}\text { tourists' revisit intention. The results from this paper provide } \\
\text { suggestions for enhancing memorable tourism experiences and } \\
\text { encouraging tourists to return to Danang. Future studies should } \\
\text { replicate the study in diverse samples such as geographic regions } \\
\text { participants with different travel motives. Besides, future research } \\
\text { should include destination attributes since tourists' perceptions of } \\
\text { the destination after the trip are based on on-site experiences and } \\
\text { determine memorable tourism experiences. }\end{array}$ \\
\hline
\end{tabular}

\section{Introduction}

Locating in the critical economics region of Central Vietnam, Danang tourism is famous with natural endowments, international airport, international seaport, well-developed accommodation, diversified tourism products (such as sea, resort, culture, sightseeing, villages). Tourism is considered as a spearhead economic sector that has been contributing to Danang City development. According to Danang Tourism Department $(2016,2017)$, the annual average growth rate of tourists in the period of 2011 - 2015 is 20.14\%. By 2016, the total number of domestic tourists increased by $12.5 \%$ compared to 2015 , accounting for a high proportion $(69.74 \%)$ in the structure of total tourists to Da Nang. Total tourism revenue in the period of $2011-2015$ increased by an average of $30.7 \%$ annually. In 2016, 2017, total tourism revenue increased by over $24 \%$ compared to the previous year. Only in 2016, Danang tourism, whose revenue is approximately 16.5trillion VND (23.72\% of gross product), has created over 140 thousand jobs $(25.43 \%$ of total employment). The number of domestic tourists was 3.3million in 2015 (71.7\% of total tourists) and increased to 3.84 million in 2016 (69.7\% of total tourists).

Besides the advantages of sea resort tourism, MICE tourism (meetings, incentives, 
conferences, and exhibitions) and entertainment services in Danang have become more and more abundant. Leisure places in Danang such as Fantasy Park, Ba Na-Suoi Mo eco-tourism complex, Asian park, Helio Center, and shopping centers such as Indochina tower, Vincom plaza, VinhTrung Plaza are useful in attracting tourists. However, in a report of the Tourism department in April 2016, the percentage of second-time domestic tourists is 58.6\% which is not as high as expected. Hence, paying attention to the revisit rate of domestic travelers is one of the striking issues for Danang destination management. Thus, in this research, we focus on how to improve the return rate of tourists to Danang City.

This study departs from the previous research considers investigating some traditional factors that drive consumers' revisit intention, such as destination image, tourism motivation, satisfaction, and perceived quality, by emphasizing the role of memorable tourism experience (MTE, hereafter). Previous research mentioned the important role of memorable tourism experience as the most impact factor influencing the planning behavior before the trip (Kim, 2017), or the essential information source for return intention (Oh, Fiore, \& Jeoung, 2007). However, it is a surprise of scant research in Vietnam focusing on explaining the return intention of tourists from a memorable experience perspective.

Additionally, defining and measuring MTE for a specific destination can offer accurate information for destination managers (Kim \& Ritchie, 2013; Kim, Ritchie, \& McCormick, 2012). Hence, this study aims to understand the impact of MTE on the revisit intention of Danang domestic tourists. In particular, as multiple dimensions construct, each dimension of MTE will be investigated. The results provide theoretical and managerial implications in enhancing the memorable tourism experience of tourists.

\section{Theoretical framework}

\subsection{Literature review}

\subsubsection{Tourism experience and memory}

Tourism is an experience-based industry in which the experience is considered as the subjective mental state perceived by participants (Otto \& Ritchie, 1996). There are several theoretical perspectives in approaching tourism experience, such as service quality (Otto \& Ritchie, 1996), attribution theory (Jackson, White, \& Schmierer, 1996), authenticity (Wang, 1999), intimacy theory (Trauer \& Ryan, 2005). This research follows the definition of Tung and Ritchie (2011, p. 1369), in which tourism experience is "individual subjective evaluation and undergoing (i.e., affective, cognitive, and behavioral) of events related to his/her tourist activities." The experience is all things that tourists experience during (planning and preparation), during (at the destination), and after (recollection) of their trip to a destination. This definition addresses the importance of tourism planning to support the development of memorable tourist experiences and reveals the doubt of using 'one-size-fits-all' approach in creating memorable tourism experiences (Henderson \& Tsui, 2019).

Pine and Gilmore (1999) indicate four realms of experience are entertainment, education, esthetics, escapism (Oh et al., 2007). Pine and Gilmore (1999) suppose that a positive experience can shape memory which is remembering a particular event. Creating good memories related to the destination experience is useful in forming a positive attitude toward the destination of tourists. Reversely, bad experiences will lead to a vivid memory which is the antecedent of a negative reaction. Since sensorial experiences are easier to memorize than non-emotional experiences, they can boost memories (Dolcos \& Cabeza, 2002). Moreover, Tung and Ritchie (2011) explore the essence of memorable experiences on psychological views related to memory formation and 
retention. Agapito, Valle, and Mendes (2014) concentrate on the sensory dimension of positive tourist experiences in terms of sensory-informed experiences as the enabler. Agapito, Pinto, and Mendes (2017) give the supplement on diversified sensory impressions that can affect tourists' long-term memory. Likewise, Zatori, Smith, and Puczko (2018) highlight the influence of interactive service elements and experience involvement on memorability and perceived authenticity. In service, experience is a predictor of behavioral intentions (Otto, 1997). Lin and Kuo (2016) consider the behavioral consequences of tourist experience and find a mechanism of the way leads to tourist loyalty through perceived value and tourist satisfaction. Ali, Hussain, and Ragavan (2014) also prove tourists' experiences influence the memories and loyalty of customers.

\subsubsection{Memorable tourism experience}

Kim et al. (2012) propose MTE is selectively formed from tourism experiences, of which the basis is the individual's evaluation. Tsai (2016) summarizes the previous studies and concludes that memorability should be considered as the essential outcome of the tourist experience. Since not all tourist experiences are memorable tourism experiences, the author agrees with the concept of Kim et al. (2012) that MTE is a tourism experience regarding positive memories formed after a person goes through unique and surprising tourism activities. Being considered as the first study on building and testing measurement scale of memorable tourism experience, the research of Kim et al. (2012) proposes seven dimensions, including Hedonism, Refreshment, Novelty, Local Culture, Knowledge, Meaningfulness, Involvement. The authors explore individuals tend to memorize a positive experience much more than a negative experience. Later researchers can consider memories and intention at every stage of experience (planning, real experience, recalling) and define environmental elements that enhance the ability to form a memorable experience.

As an extension of the previous version, the study of Kim and Ritchie (2013) aims to test the measurement scale in different countries that Taiwan is chosen in this case. The behavioral intention here includes revisit, reattending activities, word of mouth. The result shows that only two hypotheses related to Knowledge and Meaningfulness have not been accepted. Entertainment tourism-oriented research of Chandralal and Valenzuela (2015) explore some more factors such as local hospitality, serendipitous and surprising experiences, impressive local guides, and tour operators. Almost remaining elements are similar to ones of Kim et al. (2012) which are authentic local experiences (Local Culture), novel experiences (Novelty), self-beneficial experiences (Knowledge), significant travel experiences, fulfillment of personal travel interests, emotions (Meaningfulness), social interaction (Involvement).

The scale of Kim et al. (2012) is applied by Tsai (2016) in terms of food tourism in Taiwan, Sthapit, and Coudounaris (2018) that add the element of subjective well-being and propose destination attributes as an antecedent of the memorable experience. Kim (2017) again tests relationships between a memorable experience and destination image, overall satisfaction, revisit intention, word of mouth. No matter is affecting directly or indirectly to plan; an unforgettable experience is proved as the most influential element. Although becoming more popular in recent years, the memorable tourism experience has not been found in any research in Vietnam.

\subsubsection{Revisit intention}

Similar to customer retention, attracting tourists to return to a destination is one of the critical concerns of destination marketers. Additionally, Pedersen and Nysveen (2001) prove that conative loyalty (among four forms of loyalty that are categorized by a commitment for repurchase) is the strongest predictor of customer loyalty. The intention can be the predictor of behavior in terms of action, target, context, and time (Ajzen, 1985). Behavioral intentions are 
affected by performance quality and satisfaction, which is the quality of experience. A revisit intention is a form of behavioral plan mentioned by Baker and Crompton (2000). Y.-J. Lee (2015) supposes that revisit intention is related to the frequencies of visiting a tourist destination. In the research of $\mathrm{Hu}$ (2003), revisit intention (a cognitive situation that reflects the plan of tourist to return to a destination at the planned time) is placed concerning visit experience and mediated by post-evaluation. It means that travelers' experiences have an influence on their decisions on future visitation.

\subsection{Conceptual framework and hypothesis development}

Kim et al. (2012) indicates the memorable tourism experience, which relates to individual recall from their experience, contain seven dimensions: Hedonism, Novelty, Local Culture, Refreshment, Meaningfulness, Involvement, and Knowledge. This study applies Kim et al.'s (2012) scale of MTE that has become popular across previous studies (Y.-J. Lee, 2015; Sthapit \& Coudounaris, 2018; Tsai, 2016) and is almost similar to the new scale of Chandralal and Valenzuela (2015). The conceptual framework is shown in Figure 1.

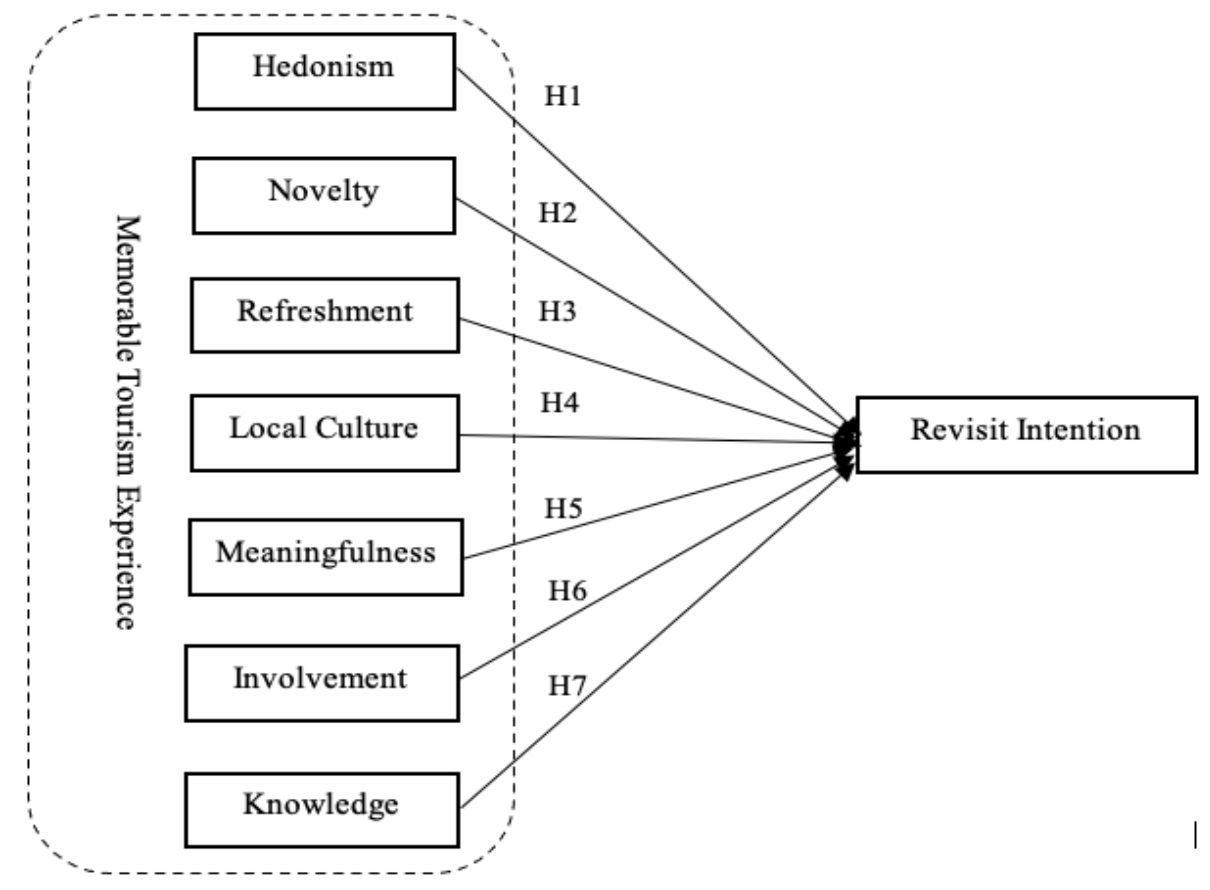

Figure 1. Conceptual framework

Hedonism is defined as pleasurable feelings that excite oneself (Kim et al. (2012) propose based on previous studies (Duman \& Mattila, 2005; Y. Lee, Dattilo, \& Howard, 1994; Otto \& Ritchie, 1996)). Hedonism is the essential purpose of tourists and the critical aspect of tourism experience and strongly affects behavior (Kim \& Ritchie, 2013). It illustrates the emotions such as pleasure, excitement, and enjoyment (Chandralal \& Valenzuela, 2015). Besides, Hedonism is similar to hedonic, including excitement, enjoyment, memorability mentioned by Otto and Ritchie (1996). According to the authors, hedonics are related to doing memorable, thrilling, new, and different things tourists like to do that bring them the feelings of once in a lifetime, escape, challenged, stirred imagination, and can share later.

Novelty is a psychological feeling of newness exceeded from having a new experience (Duman \& Mattila, 2005; Farber \& Hall, 2007). It represents the unique experiences/adventure of travelers during their memorable trips (Chandralal \& Valenzuela, 2015). Novelty seeking is an essential factor of tourist motivation, and it influences the decision-making of tourists. 
According to Kim et al. (2012), Refreshment is a state of being refreshed (Hull \& Michael, 1995; Samdahl, 1991; Tinsley, Hinson, Tinsley, \& Holt, 1993), the essential component of tourism activities and affect the ability to memorize the trip. Refreshment and newness are the features of tourism that differentiate tourism experiences from daily life (Kim \& Ritchie, 2013).

Local Culture is the component explored by Kim et al. (2012) that includes good impressions about local people, intimately experienced the local culture, friendliness. It is not only about social interaction mentioned by the earlier scholars but emphasizes the experiences of the destination culture also. Local Culture can be enhanced through unique transportation mode usage, traditional type of accommodation, localized tours with traditional markets observation. Kim and Ritchie (2013) suppose that the trip can be more memorable with the Local Culture. Likewise, Chandralal and Valenzuela (2015) propose that a tourism program that contains the local culture and hospitality of local people can create positive memories about the destination.

Meaningfulness - a sense of high value or significance - as Kim et al. (2012) synthesize from the earlier researchers (Bruner, 1991; Jamal \& Hollinshead, 2001; Noy, 2004; Wilson \& Harris, 2006), strongly affect tourists' memories (Kim \& Ritchie, 2013). According to Tung and Ritchie (2011), meaningful experiences can change tourists' minds in the long term emotionally affect their lifestyles. They are catalysts of belief changes, helpful in opening world view and become the most memorable experiences in individual life.

Kim and Ritchie (2013) emphasize personal relevance aspects of tourists when mentioning Involvement. Depending level of emotions and expectations of a person during his/her planning stage for a trip, the participation at the on-site activities stage will decide MTEs. Involvement is doing personal traveling hobbies, representing travelers' active participation in MTEs (Chandralal \& Valenzuela, 2015).

According to Kim et al. (2012), Knowledge is information, facts, or experiences known by an individual. Tung and Ritchie (2011) suppose that attaining new knowledge about the destination is related to learning the history, culture, way-of-life, local language, natural physiography. It can be considered as a fresh, eye-opening experience, similar to the "push" factor of tourism as mentioned by Kim and Ritchie (2013) that negatively affects behavioral intention. It means that the more individuals learn or familiarize themselves with the destination, the less they find the locality is novel, their motivation to discover decreases. Although this negative relationship is not significant in the study of Kim and Ritchie (2013), a similar result is implied in the relationship between education and loyalty through vivid memory (Manthiou, Lee, Tang, \& Chiang, 2014).

Thus, based on these arguments, this study formulates the hypothesis:

The MTE scale's dimensions (Hedonism (H1), Novelty (H2), Refreshment (H3), Local Culture (H4), Meaningfulness (H4), Involvement (H5), and Knowledge (H6)) influence on domestic tourist's revisit intention to Danang City.

\section{Research method}

Mix methodology is applied in this study. First, the qualitative stage is conducted through an in-depth interview to explore and modify measurements of memorable tourism experiences. Interviewees are people who have working experience in the tourism industry in Danang. The official measurement scale is shown in Table 1. As can be seen, two items related to Local Culture are added to the original scale in a qualitative stage. In particular, delicious cuisine represents fresh seafood, Quang noodles, pancake, or canned foods such as dry sesame bread fish sauces. This idea is consistent with the statement of Tsai (2016) that cuisine can tell a story about history the culture of a place and is helpful in forming memorable tourism experiences. Additionally, traditional festivals such as Quan-The-Am festival, Cau-Ngu (Whale) festival, village communal house festivals should be paid attention to when mentioning Local Culture. 


\section{Table 1}

The measurement scale for designing a structured questionnaire

\begin{tabular}{|c|c|c|}
\hline Code & Items & Authors \\
\hline \multicolumn{3}{|c|}{ Hedonism } \\
\hline $\begin{array}{l}\text { Hed1 } \\
\text { Hed2 } \\
\text { Hed3 } \\
\text { Hed4 }\end{array}$ & $\begin{array}{l}\text { I am thrilled to have new experiences in Danang } \\
\text { I indulged in the tourism activities in Danang } \\
\text { I really enjoyed this tourism experience } \\
\text { I was so excited about the Danang trip }\end{array}$ & $\begin{array}{l}\text { Kim et al. (2012), Kim and } \\
\text { Ritchie (2013), Chandralal } \\
\text { and Valenzuela (2015), } \\
\text { Sthapit and Coudounaris } \\
(2018)\end{array}$ \\
\hline \multicolumn{3}{|l|}{ Novelty } \\
\hline $\begin{array}{l}\text { Nov3 } \\
\text { Nov4 }\end{array}$ & $\begin{array}{l}\text { I had a once-in-a-lifetime experience in Danang } \\
\text { I had a unique experience in Danang } \\
\text { My experience in Danang is different from previous } \\
\text { experiences of mine } \\
\text { I experienced something new in Danang }\end{array}$ & $\begin{array}{l}\text { Kim et al. (2012), Kim and } \\
\text { Ritchie (2013), Chandralal } \\
\text { and Valenzuela (2015), } \\
\text { Sthapit and Coudounaris } \\
(2018)\end{array}$ \\
\hline
\end{tabular}

\section{Local Culture}

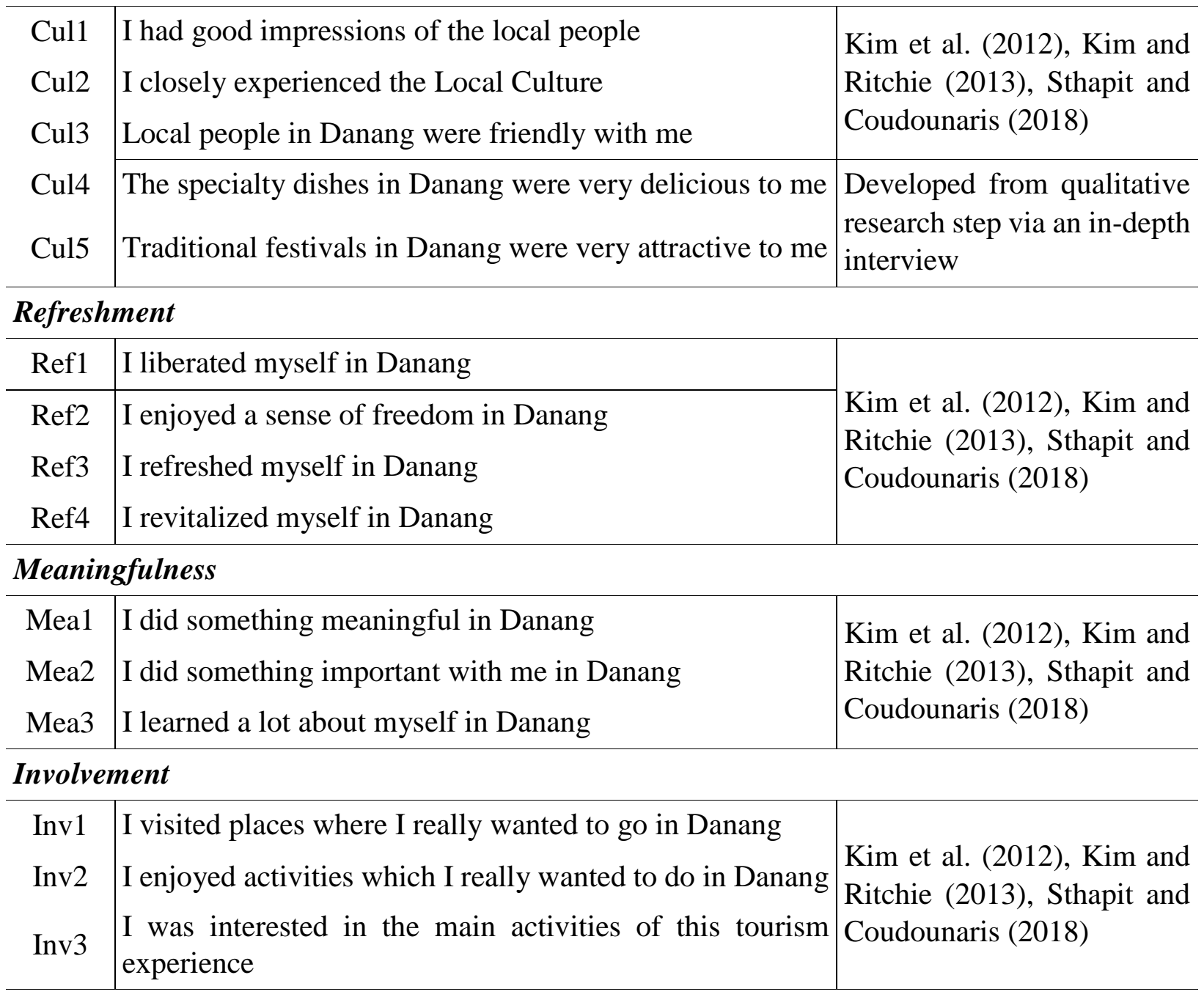




\begin{tabular}{|c|c|c|}
\hline Code & Items & Authors \\
\hline \multicolumn{3}{|c|}{ Knowledge } \\
\hline $\begin{array}{l}\text { Kno1 } \\
\text { Kno2 } \\
\text { Kno3 }\end{array}$ & $\begin{array}{l}\text { I explored many new things during my trip to Danang } \\
\text { I learned more Knowledge (e.g., history, slang, geography, } \\
\text { food, sport, etc.) during my trip to Danang } \\
\text { I knew the new culture from my trip to Danang }\end{array}$ & $\begin{array}{l}\text { Kim et al. (2012), Kim and } \\
\text { Ritchie (2013), Sthapit and } \\
\text { Coudounaris (2018) }\end{array}$ \\
\hline \multicolumn{3}{|c|}{ Revisit Intention } \\
\hline $\begin{array}{l}\text { Int1 } \\
\text { Int } 2 \\
\text { Int3 }\end{array}$ & $\begin{array}{l}\text { I can return to Danang in the future } \\
\text { I want to return to Danang in the future } \\
\text { I plan to return to Danang in the future }\end{array}$ & $\begin{array}{l}\text { Yoon and Uysal (2005), } \\
\text { Manthiou et al. (2014), Kim } \\
(2017)\end{array}$ \\
\hline
\end{tabular}

Source: Adopted from previous studies

Second, the quantitative stage uses the structured questionnaire (with a 5-point Likert scale) that contains the itemsadapted from previous research and from the qualitative stage. Pretesting was conducted with 50 respondents to check whether the questionnaire was easy to understand. The sample size meets the requirement as proposed by Hair, Black, Babin, and Anderson (2009) that it should be equal to or greater than five times of items (here is 5 x $29=145$ ) and should be 200 for running Structural Equation Modelling. Convenient and snowball sampling is chosen because of approach domestic tourists.

After finishing the official survey, the information is filtered and coded into SPSS 16.0. The study tests the reliability (testing Cronbach's Alpha), the validity (Exploration Factor Analysis with SPSS, Confirmatory Factor Analysis with AMOS 20.0), and Structured Equation Model (with AMOS 20.0) to test the conceptual model and all hypotheses.

\section{Results}

\subsection{Data description}

The data of 309 respondents show $42.7 \%$ of the age between 23 - 35, the tourists between 36 - 50 accounted for $33.3 \%$. The people at these ages are independent, have jobs with stable income, and are actively in tourism decisions. $71.2 \%$ of respondents are females, compared to $28.8 \%$ are males. The domestic tourists' income is high $(38.8 \%$ of respondents with income level is at least 20million VND per month, 30.4\% with an income level between 10 - 20million VND per month, only $6.1 \%$ with income under 05 million VND per month). The majority of tourists come from Ho Chi Minh City, Hanoi, and Hai-Phong (accounted for 35.6\%, 23\%, 14.9\%, respectively). In terms of trip characteristics, $51.8 \%$ of respondents are one-time visitors (compared to $10 \%$ of respondents with visiting frequencies being greater than five). The length of stay was mainly around 03 - 04 days (42.4\%), followed by 01 - 02 day(s) (31.7\%), and more than five days (25.9\%). Almost respondents travel with their friends/relatives/spouses (63.4\%) for tourism/relax only (43.9\%), visiting friends/relatives $(25.5 \%)$, or business trips/meetings/ conferences $(21.3 \%)$.

Additionally, to select a destination, tourists care about social security (mean $=4.44$ ), natural landscapes (mean $=4.39$ ), followed by entertainment services, restaurants, and cuisine, environment and climate, friendliness of local people, events and festivals, infrastructure, accommodation/resort facilities, shopping places, historical sites, and cultural heritage, handicraft villages (see Table 2). 
As shown in Table 2, Danang is perceived as good at social security, natural landscapes, accommodation/resort facilities, infrastructure, friendliness of local people. Excepting events and festivals, souvenirs, the remaining elements are not highly evaluated (almost lower than 3.5). As can be seen, Danang tourism exploits advantages on nature; cultural tourism is not strong enough (such as various shopping spots, entertainment activities, villages). Besides, the government needs to pay more attention to food hygiene to encourage tourists to consume and return.

In the memorable tourism experience dimension, the items about attractive traditional festivals (belongs to Local Culture), exploratory (belongs to Knowledge) that their means are not exceeded to 2.6 (equivalent to disagreement). Reversely, the items about delicious specialty dishes (Local Culture), really enjoyed this tourism experience (Hedonism) are highly evaluated (3.66 and 3.61 respectively). Regarding revisit Intention, all items are at a medium level (ranging from 2.82 to 3.34$)$.

\section{Table 2}

Concerns of tourists for destination selection and their evaluation on Danang

\begin{tabular}{lcccc}
\hline \multirow{2}{*}{ Contents } & For destination selection & \multicolumn{2}{c}{ Danang evaluation } \\
\cline { 2 - 5 } & Mean & Std & Mean & Std \\
\hline Natural landscapes & 4.39 & 0.716 & 4.26 & 0.741 \\
\hline Environment, climate & 4.12 & 0.811 & 0.00 & 0.000 \\
\hline Infrastructure & 4.00 & 0.851 & 3.79 & 0.843 \\
\hline Historical sites and cultural heritage & 3.64 & 0.914 & 3.32 & 0.976 \\
\hline Accommodation/resort facilities & 3.97 & 0.837 & 4.11 & 0.840 \\
\hline Entertainment & 4.25 & 0.832 & 3.35 & 0.730 \\
\hline Cuisine & 4.23 & 0.804 & 3.71 & 1.056 \\
\hline Food hygiene & 0.00 & 0.000 & 3.25 & 0.746 \\
\hline Shopping places & 3.70 & 0.840 & 3.24 & 0.674 \\
\hline Souvenirs & & & 3.51 & 0.719 \\
\hline Friendliness of local people & 4.06 & 0.849 & 3.63 & 1.078 \\
\hline Social security & 4.44 & 0.698 & 4.25 & 0.719 \\
\hline Events and festivals & 4.05 & 0.817 & 3.55 & 0.778 \\
\hline Handicraft villages & 3.46 & 0.913 & 3.33 & 0.899 \\
\hline
\end{tabular}

Source: Data analysis of the study

\subsection{Scale's reliability and validity}

All seven independent components and one dependent variable have been tested the reliability before testing validity. Since this study is the first one conducted in Vietnam, the cutoff for Cronbach's Alpha is 0.6 and for item-total correlation is 0.3 (Sekaran, 2006). We only eliminate Cul5-attractive traditional festivals (with item-total correlation is equal to 0.161, and the Cronbach's Alpha of Local Culture will be increased to 0.893 if this item is deleted). This elimination is reasonable since this item is added after the qualitative stage and the respondents' evaluation of it is low (from data description result). Besides, the Cronbach's Alpha coefficients 
of the six remaining variables are greater than 0.8 represents a good measurement scale (Hair et al., 2009). The 28 remaining items are inputted for Exploratory Factor Analysis (EFA).

The EFA results show the KMO value is 0.868 (>0.5), with the significance of Bartlett's test being less than 0.05 ( sig. $=0.000$ ) which means the data is consistent for EFA (Coakes \& Steed, 2009). At Eigenvalue greater than 1, with the principal axis factoring and Promax rotation, there are 08 factors extracted from 28 items with total variance is $71.48 \%$ (> 50\%). The factors extracted are the same as the original model. All factor loadings are higher than 0.5, and discriminant values are ensured, so EFA result is accepted for Confirmatory Factor Analysis (CFA).

\section{Table 3}

The result of CR, AVE and correlation matrix

\begin{tabular}{l|c|c|cccccccc}
\hline \multicolumn{1}{c|}{ Factor } & CR & AVE & $\mathbf{1}$ & $\mathbf{2}$ & $\mathbf{3}$ & $\mathbf{4}$ & $\mathbf{5}$ & $\mathbf{6}$ & $\mathbf{7}$ & $\mathbf{8}$ \\
\hline 1. Refreshment & 0.903 & 0.699 & $\mathbf{0 . 8 3 6}$ & & & & & & & \\
2. Local Culture & 0.896 & 0.686 & 0.354 & $\mathbf{0 . 8 2 8}$ & & & & & \\
3. Novelty & 0.881 & 0.650 & 0.239 & 0.283 & $\mathbf{0 . 8 0 6}$ & & & & \\
4. Hedonism & 0.889 & 0.688 & 0.373 & 0.432 & 0.148 & $\mathbf{0 . 8 1 7}$ & & & & \\
5. Involvement & 0.909 & 0.769 & 0.214 & 0.326 & 0.126 & 0.228 & $\mathbf{0 . 8 7 7}$ & & \\
6. Knowledge & 0.875 & 0.693 & 0.176 & 0.138 & 0.400 & 0.179 & 0.055 & $\mathbf{0 . 8 3 7}$ & \\
$\begin{array}{l}\text { 7. Meaning- } \\
\text { fulness }\end{array}$ & 0.871 & 0.771 & 0.332 & 0.405 & 0.382 & 0.520 & 0.344 & 0.205 & $\mathbf{0 . 8 3 2}$ & \\
8. Revisit & & & & & & & & & & \\
intention & 0.910 & 0.771 & 0.243 & 0.403 & 0.342 & 0.367 & 0.301 & 0.279 & 0.248 & $\mathbf{0 . 8 7 8}$ \\
\hline
\end{tabular}

Notes: Values above the diagonal are the square root of AVE; Values below the diagonal are correlation coefficients Source: Data analysis of the study

CFA results show that Chi-square $=545.452, \mathrm{df}=322, \mathrm{p}=0.000$, Chi-square $/ \mathrm{df}=1.694$ $(<3), \mathrm{CFI}=0.961, \mathrm{TLI}=0.955(\geq 0.90), \mathrm{RMSEA}=0.047(<0.08), \mathrm{SRMR}=0.058(<0.09)$, so the model in accordance with market data (Hair et al., 2009). Besides, the reliability, convergence validity, and discriminant validity are also tested. The results of Cronbach alpha of constructs are higher than the threshold of 0.7, indicating the instruments are highly reliable (Sekaran, 2006). For the convergence validity, the composite reliability (CR) and the Average Variance Extracted (AVE) should be higher than the threshold of 0.7 and 0.5, respectively (Fornell \& Larcker, 1981). Table 3 shows the CR and AVE of all constructs exceed the threshold, indicating the confirmation of convergence validity. Moreover, Table 3 shows th at the square root of AVE of each construct is higher than its correlation with other constructs, indicating the discriminant validity (Fornell \& Larcker, 1981).

\subsection{Hypothesis testing}

To estimate the relationships between structures in the proposed framework, the authors use Structural Equation Modelling (SEM). The results reflect the appropriateness of the SEM as follows: Chi-square adjusted by degrees of freedom (CMIN/df) is $1.694(<2), \mathrm{CFI}=0.961$ and TLI $=0.955$ (> 0.90), RMSEA = 0.047 (Hair et al., 2009). Testing hypotheses results are shown in Table 4. 


\section{Table 4}

Testing hypotheses

\begin{tabular}{|c|c|c|c|c|c|}
\hline Hypothesis & $\begin{array}{c}\text { Independent } \\
\text { Variables }\end{array}$ & $\begin{array}{c}\text { Dependent } \\
\text { variable }\end{array}$ & $\begin{array}{l}\text { Standardized } \\
\text { coefficient }(\beta)\end{array}$ & $\begin{array}{c}\text { P- } \\
\text { value }\end{array}$ & Conclusion \\
\hline H1 & Hedonism & $\begin{array}{l}\text { Revisit } \\
\text { Intention }\end{array}$ & 0.167 & 0.008 & Accepted \\
\hline $\mathbf{H 2}$ & Novelty & $\begin{array}{l}\text { Revisit } \\
\text { Intention }\end{array}$ & 0.329 & $* * *$ & Accepted \\
\hline H3 & Refreshment & $\begin{array}{l}\text { Revisit } \\
\text { Intention }\end{array}$ & 0.021 & 0.680 & Not accepted \\
\hline H4 & Local Culture & $\begin{array}{l}\text { Revisit } \\
\text { Intention }\end{array}$ & 0.130 & 0.033 & Accepted \\
\hline H5 & Meaningfulness & $\begin{array}{l}\text { Revisit } \\
\text { Intention }\end{array}$ & 0.081 & 0.233 & Not accepted \\
\hline H6 & Involvement & $\begin{array}{l}\text { Revisit } \\
\text { Intention }\end{array}$ & 0.163 & $* * *$ & Accepted \\
\hline H7 & Knowledge & $\begin{array}{l}\text { Revisit } \\
\text { Intention }\end{array}$ & -0.244 & $* * *$ & Accepted \\
\hline
\end{tabular}

Notes: $* * * \mathrm{p}<0.01$

Source: Data analysis of the study

As can be seen, four among seven components in memorable tourism experience measurement scale have positive influences on revisit intention including Novelty $(\beta=0.366)$, Involvement $(\beta=0.187)$, Hedonism $(\beta=0.163)$, Local Culture $(\beta=0.119)$. Among them, Novelty is the strongest element that affects Revisit Intention of tourists. Knowledge $(\beta=-0.237)$ has a negative influence on Revisit Intention, similar to the result in the study of Kim and Ritchie (2013). Hypothesis 3 and Hypothesis 5 are not accepted because of no statistical significance. $\mathrm{R}$ square is equal to 0.545 means that Novelty, Involvement, Hedonism, Local Culture, Knowledge can explain $54.5 \%$ of the variation of Revisit Intention of Danang domestic tourists.

\section{Discussion and implication}

Among seven components of the MTE, five elements significantly explain $54.5 \%$ of the variance of revisit intention. In particular, Novelty is the most influential variable of revisit intention of domestic tourists with Danang City as a tourism destination. Besides, other three factors, Involvement, Hedonism, and Local Culture, also positively influence the revisit intention of tourists. In opposite, Knowledge is not the driver for revisit intention. The result shows the negative influence of Knowledge to revisit intention. This result can be explained by the nature tourism products of Danang City that is not support for "travel for knowledge" purpose. Danang is a young city and not a historical place when compared to its neighbors (e.g., Hue ancient capital, Hoi-An old town, or My-Son). Thus, the tourism of Danang is more focused on relaxation purpose than learning purpose. The adverting campaign and the proportion of tourism products in Danang reveal the heavy investigation on entertainment orientation which make the city is different from its neighbor competitors. This reason can explain why tourists don't think seeking Knowledge is the driver for them to return to Danang in the future. When individuals have already learned and 
are familiarized with a destination, it is hard for them to return to the previously visited destination with the purpose of learning something new (Kim \& Ritchie, 2013).

This research has some main implications for both academics and practice. For theoretical implication, by measuring the influence of memorable tourism experience on revisit intention, this research contributes to the body of tourism experience literature. In addition, this research applies mixed methodology on developing a set of measurement scales of MTE in the Vietnam context. Thus, this research provides empirical evidence for the MTE research stream and also provides a validity and reliability scale for future research on this topic in Vietnam.

For managerial implication, this is the first study exploring the relationship between memorable tourism experience and revisit intention in the case of Danang City. Hence, it contributes to providing some useful information for Danang tourism management. In particular, to enhance novelty-the most important factor, Danang needs to differentiate itself from the other destinations in Vietnam refresh tourism products continuously while keeping its core features. In spite of high efforts in creating modern festivals and events, Danang has not been promoted the traditional ones efficiently. The city marketers can consider combining traditional celebrations with local cuisine, increasing the Involvement of tourists to boost their thrilled feelings through activities. The communication messages should emphasize the uniqueness of the places, cuisines, or activities. The Local Culture related to history and the native culture of the Champa lost kingdom can be mentioned. Why is Danang considered as a young city while the story began hundreds of years ago? Why did French, Americans choose this locality in the past as a strategic center? What does Danang have to become a spearhead urban of Central Vietnam only within 22 years? All these concerns should be questioned to stimulate the curiosity of tourists before, during, and even after their visits. Besides, ensuring a clean, beautiful environment along with taking the role as a logistics center of Central can enhance the Hedonism of tourists.

We also provide some directions for future research. Since there is a lack of studies on memorable tourism experiences, similar studies can be conducted with other cases of Vietnam cities. Then the researchers can make a comparison between cities with the same conditions. Future research also can exploit the environmental elements to form memorable experiences in tourists' minds. Furthermore, the limitation of available sampling is the representation of the sample size. So further research can choose different groups with more diverse demographics and psychology.

\section{References}

Agapito, D., Pinto, P., \& Mendes, J. (2017). Tourists' memories, sensory impressions and loyalty: In loco and post-visit study in Southwest Portugal. Tourism Management, 58, 108-118. doi:10.1016/j.tourman.2016.10.015

Agapito, D., Valle, P., \& Mendes, J. (2014). The sensory dimension of tourist experiences: Capturing meaningful sensory-informed themes in Southwest Portugal. Tourism Management, 42, 224-237. doi:10.1016/j.tourman.2013.11.011

Ajzen, I. (1985). From intentions to actions: A theory of planned behavior. In J. Kuhl \& J. Beckmann (Eds.), Action control: From cognition to behavior (pp. 11-39). Berlin, Heidelberg: Springer Berlin Heidelberg.

Ali, F., Hussain, K., \& Ragavan, N. A. (2014). Memorable customer experience: Examining the effects of customers experience on memories and loyalty in Malaysian resort hotels. Procedia - Social and Behavioral Sciences, 144, 273-279. doi:10.1016/j.sbspro.2014.07.296 
Baker, D. A., \& Crompton, J. L. (2000). Quality, satisfaction and behavioral intentions. Annals of Tourism Research, 27(3), 785-804. doi:10.1016/S0160-7383(99)00108-5

Bruner, E. M. (1991). Transformation of self in tourism. Annals of Tourism Research, 18(2), 238250. doi:10.1016/0160-7383(91)90007-X

Chandralal, L., \& Valenzuela, F.-R. (2015). Memorable tourism experiences: Scale development. Contemporary Management Research, 11(3), 291-310. doi:10.7903/cmr.13822

Coakes, S. J., \& Steed, L. (2009). SPSS Version 20.0 for Windows: Analysis without Anguish. Hoboken, NJ: John Wiley \& Sons, Inc.

Danang Tourism Department. (2016). Báo cáo kết quả hoạt động du lịch năm 2016 và phuơng huoóng, nhiệm vu năm 2017 [Report on tourism performance in 2016 and directions and tasks in 2017]. Danang, Vietnam: Danang Tourism Department.

Danang Tourism Department. (2017). Báo cáo kết quả hoạt động du lịch năm 2017 và phuơng huớng, nhiệm vu năm 2018 [Report on tourism performance in 2017 and directions and tasks in 2018]. Danang, Vietnam: Danang Tourism Department.

Dolcos, F., \& Cabeza, R. (2002). Event-related potentials of emotional memory: Encoding pleasant, unpleasant, and neutral pictures. Cognitive, Affective, \& Behavioral Neuroscience, 2(3), 252-263. doi:10.3758/cabn.2.3.252

Duman, T., \& Mattila, A. S. (2005). The role of affective factors on perceived cruise vacation value. Tourism Management, 26(3), 311-323. doi:10.1016/j.tourman.2003.11.014

Farber, M. E., \& Hall, T. E. (2007). Emotion and environment: Visitors' extraordinary experiences along the Dalton Highway in Alaska. Journal of Leisure Research, 39(2), 248-270. doi:10.1080/00222216.2007.11950107

Fornell, C., \& Larcker, D. F. (1981). Evaluating structural equation models with unobservable variables and measurement error. Journal of Marketing Research, 18(1), 39-50. doi: $10.1177 / 002224378101800104$

Hair, J. F., Black, W. C., Babin, B. J., \& Anderson, R. E. (2009). Multivariate data analysis. Upper Saddle River, NJ: Prentice Hall.

Henderson, I. L., \& Tsui, W. H. K. (2019). The role of niche aviation operations as tourist attractions. In A. Graham \& F. Dobruszkes (Eds.), Air transport: A tourism perspective (pp. 233-244). London, UK: Elsevier.

$\mathrm{Hu}, \mathrm{B}$. (2003). The impact of destination involvement on travelers' revisit intentions. (Doctoral dissertation ). Purdue University, West Lafayette, Indiana.

Hull IV, R. B., \& Michael, S. E. (1995). Nature-based recreation, mood change, and stress restoration. Leisure Sciences, 17, 1-14. doi:10.1080/01490409509513239

Jackson, M. S., White, G. N., \& Schmierer, C. L. (1996). Tourism experiences within an attributional framework. Annals of Tourism Research, 23(4), 798-810. doi:10.1016/01607383(96)00003-5

Jamal, T., \& Hollinshead, K. (2001). Tourism and the forbidden zone: The underserved power of qualitative inquiry. Tourism Management, 22(1), 63-82. doi:10.1016/S02615177(00)00020-0 
Kim, J.-H. (2017). The impact of memorable tourism experiences on loyalty behaviors: The mediating effects of destination image and satisfaction. Journal of Travel Research, 57(7), 856-870. doi:10.1177/0047287517721369

Kim, J.-H., \& Ritchie, J. R. B. (2013). Cross-cultural validation of a Memorable Tourism Experience Scale (MTES). Journal of Travel Research, 53(3), 323-335. doi:10.1177/0047287513496468

Kim, J.-H., Ritchie, J. R. B., \& McCormick, B. (2012). Development of a scale to measure memorable tourism experiences. Journal of Travel Research, 51(1), 12-25. doi:10.1177/0047287510385467

Lee, Y.-J. (2015). Creating memorable experiences in a reuse heritage site. Annals of Tourism Research, 55, 155-170. doi:10.1016/j.annals.2015.09.009

Lee, Y., Dattilo, J., \& Howard, D. (1994). The complex and dynamic nature of leisure experience. Journal of Leisure Research, 26(3), 195-211. doi:10.1080/00222216.1994.11969956

Lin, C.-H., \& Kuo, B. Z.-L. (2016). The behavioral consequences of tourist experience. Tourism Management Perspectives, 18, 84-91. doi:10.1016/j.tmp.2015.12.017

Manthiou, A., Lee, S., Tang, L., \& Chiang, L. (2014). The experience economy approach to festival marketing: Vivid memory and attendee loyalty. Journal of Services Marketing, 28(1), 22-35. doi:10.1108/JSM-06-2012-0105

Noy, C. (2004). This trip really changed me: Backpackers' narratives of self-change. Annals of Tourism Research, 31(1), 78-102. doi:10.1016/j.annals.2003.08.004

Oh, H., Fiore, A. M., \& Jeoung, M. (2007). Measuring experience economy concepts: Tourism applications. Journal of Travel Research, 46(2), 119-132. doi:10.1177/0047287507304039

Otto, J. E. (1997). The role of the affective experience in the service experience chain (Doctoral dissertation). The University of Calgary, Calgary, Canada.

Otto, J. E., \& Ritchie, J. R. B. (1996). The service experience in tourism. Tourism Management, 17(3), 165-174. doi:10.1016/0261-5177(96)00003-9

Pedersen, P. E., \& Nysveen, H. (2001). Shopbot banking: An exploratory study of customer loyalty effects. International Journal of Bank Marketing, 19(4), 146-155. doi:10.1108/02652320110392518

Pine, B. J., \& Gilmore, J. H. (1999). The experience economy : Work is theater \& every business a stage. Boston, MA: Harvard Business School Press.

Samdahl, D. M. (1991). Issues in the measurement of leisure: A comparison of theoretical and connotative meanings. Leisure Sciences, 13(1), 33-49. doi:10.1080/01490409109513123

Sekaran, U. (2006). Research methods for business: A skill building approach. New York, NY: John Wiley \& Sons.

Sthapit, E., \& Coudounaris, D. N. (2018). Memorable tourism experiences: Antecedents and outcomes. Scandinavian Journal of Hospitality and Tourism, 18(1), 72-94. doi:10.1080/15022250.2017.1287003

Trauer, B., \& Ryan, C. (2005). Destination image, romance and place experience - An application of intimacy theory in tourism. Tourism Management, 26(4), 481-491. doi:10.1016/j.tourman.2004.02.014 
Tinsley, H. E., Hinson, J. A., Tinsley, D. J., \& Holt, M. S. (1993). Attributes of leisure and work experiences. Journal of Counseling Psychology, 40(4), Article 447. doi:10.1080/01490409109513123

Tsai, C.-T. (2016). Memorable tourist experiences and place attachment when consuming local food. International Journal of Tourism Research, 18(6), 536-548. doi:10.1002/jtr.2070

Tung, V. W. S., \& Ritchie, J. R. B. (2011). Exploring the essence of memorable tourism experiences. Annals of Tourism Research, 38(4), 1367-1386. doi:10.1016/j.annals.2011.03.009

Wang, N. (1999). Rethinking authenticity in tourism experience. Annals of Tourism Research, 26(2), 349-370. doi:10.1016/S0160-7383(98)00103-0

Wilson, E., \& Harris, C. (2006). Meaningful travel: Women, independent travel and the search for self and meaning. Tourism: An International Interdisciplinary Journal, 54(2), 161-172.

Yoon, Y., \& Uysal, M. (2005). An examination of the effects of motivation and satisfaction on destination loyalty: A structural model. Tourism Management, 26(1), 45-56. doi:10.1016/j.tourman.2003.08.016

Zatori, A., Smith, M. K., \& Puczko, L. (2018). Experience-involvement, memorability and authenticity: The service provider's effect on tourist experience. Tourism Management, 67, 111-126. doi:10.1016/j.tourman.2017.12.013 